\title{
The effect of cattle slurry in combination with nitrate and the nitrification inhibitor dicyandiamide on in situ nitrous oxide and dinitrogen emissions
}

\author{
K. L. McGeough ${ }^{1}$, R. J. Laughlin ${ }^{1}$, C. J. Watson ${ }^{1}$, C. Müller ${ }^{2,3}$, M. Ernfors ${ }^{4,5}$, E. Cahalan ${ }^{2,4}$, and K. G. Richards ${ }^{4}$ \\ ${ }^{1}$ Agri-Food and Biosciences Institute, Newforge Lane, Belfast, BT9 5PX, Northern Ireland, UK \\ ${ }^{2}$ School of Biology and Environmental Science, University College Dublin, Dublin 4, Ireland \\ ${ }^{3}$ Department of Plant Ecology, Justus-Liebig University Giessen, Heinrich-Buff-Ring 26, \\ 35392 Giessen, Germany \\ ${ }^{4}$ Teagasc, Johnstown Castle Environmental Research Centre, Co. Wexford, Ireland \\ ${ }^{5}$ Department of Agrosystems, Swedish University of Agricultural Sciences, P.O. Box 104, \\ 23053, Alnarp, Sweden
}

Correspondence to: K. L. McGeough (karen.mcgeough@afbini.gov.uk)

Received: 22 June 2012 - Published in Biogeosciences Discuss.: 24 July 2012

Revised: 5 November 2012 - Accepted: 6 November 2012 - Published: 4 December 2012

\begin{abstract}
A field study was conducted to determine the effect of the nitrification inhibitor dicyandiamide (DCD) on $\mathrm{N}_{2} \mathrm{O}$ and $\mathrm{N}_{2}$ emissions after cattle slurry (CS) application in the presence of nitrate $\left(\mathrm{NO}_{3}\right)$ fertiliser on seven different occasions (between March 2009 and March 2011).

$\mathrm{N}_{2} \mathrm{O}$ emissions from $\mathrm{CS}$ in the presence of $\mathrm{NO}_{3}$ fertiliser were very high $(0.4-8.7 \%$ of applied $\mathrm{N})$ over a 20 -day period, under mild moist conditions. Emissions were significantly larger from the CS treatment compared to an $\mathrm{NH}_{4}^{+}-\mathrm{N}$ source, supplying the same rate of $\mathrm{N}$ as in the slurry. This study supports the view that organic fertilisers should not be applied at the same time as nitrate-based fertilisers, as significant increases in $\mathrm{N}_{2} \mathrm{O}$ emissions occur. The average $\mathrm{N}_{2} \mathrm{O}$ mole fraction $\left(\mathrm{N}_{2} \mathrm{O} /\left(\mathrm{N}_{2} \mathrm{O}+\mathrm{N}_{2}\right)\right)$ over all seven application dates was 0.34 for $\mathrm{CSNO}_{3}$ compared to 0.24 for the $\mathrm{NH}_{4} \mathrm{ClNO}_{3}$ treatment, indicating the dominance of $\mathrm{N}_{2}$ emissions.

The rate of nitrification in $\mathrm{CSNO}_{3}$ was slower than in $\mathrm{NH}_{4} \mathrm{ClNO}_{3}$, and DCD was found to be an effective nitrification inhibitor in both treatments. However, as $\mathrm{N}_{2} \mathrm{O}$ emissions were found to be predominantly associated with the $\mathrm{NO}_{3}$ pool, the effect of DCD in lowering $\mathrm{N}_{2} \mathrm{O}$ emissions is limited in the presence of a $\mathrm{NO}_{3}$ fertiliser. To obtain the maximum cost-benefit of DCD in lowering $\mathrm{N}_{2} \mathrm{O}$ emissions, under mild moist conditions, it should not be applied to a nitrate contain-
\end{abstract}

ing fertiliser (e.g. ammonium nitrate or calcium ammonium nitrate), and therefore the application of DCD should be restricted to ammonium-based organic or synthetic fertilisers.

\section{Introduction}

Ammonium nitrate (AN) and calcium ammonium nitrate (CAN) are the dominant forms of fertiliser applied to grassland in UK and Ireland. $\mathrm{AN}$ contains nitrogen as $\mathrm{NH}_{4}^{+}-\mathrm{N}$ and $\mathrm{NO}_{3}^{-}-\mathrm{N}$, and $\mathrm{CAN}$ contains in addition dolomite or limestone. Fertiliser usage for grassland has been declining since the mid-1980s by $38 \%$ in UK and $33 \%$ in Ireland. Spiralling fertiliser prices (Farmers Weekly, 2012) and nitrate regulations have mostly caused the observed decline. There is now more of an incentive to use organic fertilisers to supply nitrogen $(\mathrm{N})$ in a nutrient management plan on farms, and cattle slurry is by far the most common form of organic fertiliser. On-farm nutrient management planning encourages the integrated use of both cattle slurry and inorganic fertilisers. Therefore the practice of cattle slurry being applied in the presence of $\mathrm{NO}_{3}$ is regionally relevant.

Reviews of field studies where $\mathrm{N}_{2} \mathrm{O}$ emissions were measured suggested that mineral $\mathrm{N}$ fertilisers plus organic manures resulted in higher losses than with mineral $\mathrm{N}$ fertilisers 
alone (Bouwman, 1990; Granli and Bøckman, 1994). Field studies have shown that whenever fertilisers containing $\mathrm{NO}_{3}$ and CS are applied together, or within a few days of each other, the potential exists for enhanced $\mathrm{N}_{2} \mathrm{O}$ and $\mathrm{N}_{2}$ emissions. In moist soil conditions, cumulative $\mathrm{N}_{2} \mathrm{O}$ emissions were up to 4 times greater from $\mathrm{NH}_{4} \mathrm{NO}_{3}$ followed by $\mathrm{CS}$ than from $\mathrm{NH}_{4} \mathrm{NO}_{3}$ alone (McTaggart et al., 1997). When CS was supplemented with $\mathrm{NH}_{4} \mathrm{NO}_{3}$, the loss of $\mathrm{N}_{2} \mathrm{O}$ was $2.2 \%$ compared with $1.2 \%$ for $\mathrm{NH}_{4} \mathrm{NO}_{3}$ alone (Clayton et al., 1997). In studies conducted on four occasions in 1997 , cattle slurry increased the flux of $\mathrm{N}_{2} \mathrm{O}$ by an average factor of 3 (Stevens and Laughlin, 2001a). Lampe et al. (2006) found that the combined application of slurry and mineral fertiliser increased $\mathrm{N}_{2} \mathrm{O}$ emissions by between 30 to $150 \%$ compared to emissions from $\mathrm{CAN}$ alone. It has been reported that denitrifying bacteria are capable of utilising the volatile fatty acids (VFAs) (acetate, propionate and butyrate) present in slurry as C sources (Paul et al., 1989).

Nitrification is the general term for the aerobic oxidation of reduced nitrogen $\left(\mathrm{NH}_{3}\right)$ to $\mathrm{NO}_{2}^{-}$and further to $\mathrm{NO}_{3}^{-}$by autotrophic or heterotrophic microorganisms (Coyne and Frye, 2005). Autotrophic nitrification is a two-step process carried out by chemolithotrophic bacteria, which obtain energy by oxidizing $\mathrm{NH}_{3}$ to $\mathrm{NO}_{3}^{-}$. The first step is carried out by $\mathrm{Ni}$ trosomonas bacteria and involves the sequential oxidation of $\mathrm{NH}_{3}$ to hydroxylamine and then to $\mathrm{NO}_{2}^{-}$. The second step is the oxidation of $\mathrm{NO}_{2}^{-}$to $\mathrm{NO}_{3}^{-}$by Nitrobacter bacteria.

Heterotrophic nitrification is the oxidation of organic $\mathrm{N}$ and $\mathrm{NH}_{3}$ to $\mathrm{NO}_{3}^{-}$by chemoheterotrophic bacteria and fungi who gain their energy from organic $\mathrm{C}$ instead of $\mathrm{CO}_{2}$. Oxidation of $\mathrm{NH}_{4}^{+}$is a key process in the $\mathrm{N}$ cycle having implications for the environment as non-mobile $\mathrm{NH}_{4}^{+}$is converted to mobile $\mathrm{NO}_{3}^{-}$, which, if produced in excess of plant needs, is either leached out of the root zone or is denitrified to produce $\mathrm{N}$-gases ( $\mathrm{NO}, \mathrm{N}_{2} \mathrm{O}$ and $\mathrm{N}_{2}$ ). Nitrification inhibitors are thought to act specifically on the enzyme ammonium monooxygenase, by blocking the site where ammonium is converted to $\mathrm{NO}_{2}^{-}$. This slows down the microbial conversion of $\mathrm{NH}_{4}^{+}$to $\mathrm{NO}_{3}^{-}$and hence reduces $\mathrm{NO}_{3}^{-}$build-up and associated loss processes. The rate of degradation and hence the efficacy of nitrification inhibitors are affected by soil temperature (Zerulla et al., 2001; Edmeades, 2004), pH (Keeney, 1986), moisture content (Hendrikson and Keeney, 1979; Puttanna et al., 1999) and soil organic matter content (Briggs, 1975). The mobility of nitrification inhibitors in soil may also be a factor affecting their efficacy. As DCD is highly soluble, it can be readily leached through the profile (Zerulla et al., 2001).

Denitrification can be a major $\mathrm{N}$ loss process in grassland soils. Although the final product of denitrification is the benign atmospheric gas $\mathrm{N}_{2}$, this process is not always completed and variable amounts of $\mathrm{N}_{2} \mathrm{O}$, a potent greenhouse gas (GHG), can be produced. Physical, chemical and biological factors influence the reduction of $\mathrm{N}_{2} \mathrm{O}$ to $\mathrm{N}_{2}$ (Weier et al., 1993) including soil moisture content (Davidson, 1991; Ruser et al., 2006), pH (Simek and Cooper, 2002; Cuhel et al., 2010), temperature (Bailey, 1976; Keeney et al., 1979), C supply (Parkin, 1987; Mathieu et al., 2006), soil redox conditions (Firestone and Tiedje, 1979; Tiedje, 1988) and management (Frolking et al., 1998; Liu et al., 2007).

Most attention over the last decade has been concentrated on the intermediate gaseous products of denitrification, $\mathrm{NO}$ and $\mathrm{N}_{2} \mathrm{O}$, because of their importance in tropospheric and stratospheric processes of ozone production and consumption, and radiative forcing (Davidson et al., 2000; Hall et al., 1996; Seitzinger and Kroeze, 1998). The anthropogenic inputs of reactive $\mathrm{N}$ to the environment, resulting from food and energy production, have been increasing during the last few decades and reactive $\mathrm{N}$ has been accumulating in the environment. The largest gap in knowledge is the amount of reactive $\mathrm{N}$ converted back to $\mathrm{N}_{2}$ by denitrification. Without this information it is impossible to determine the rate of accumulation of reactive $\mathrm{N}$ in all environmental reservoirs. At present reliable quantification of $\mathrm{N}_{2}$ produced in the field is rare, and estimates of how much reactive $\mathrm{N}$ is denitrified are highly uncertain.

In this study we used the ${ }^{15} \mathrm{~N}$ gas flux method in the field to determine the effect of CS and DCD in the presence of nitrate on $\mathrm{N}_{2}$ and $\mathrm{N}_{2} \mathrm{O}$ emissions on seven occasions between March 2009 and March 2011.

\section{Materials and methods}

\subsection{Study site characteristics}

The experimental grassland site was located in Hillsborough, County Down, Northern Ireland $\left(54^{\circ} 46^{\prime} \mathrm{N} ; 6^{\circ} 08^{\prime} \mathrm{W}\right)$, where experiments were conducted on seven different occasions (March, July, October 2009, March, June, October 2010 and March 2011). A new area of grassland was used for each of the seven experimental applications. The sward was dominated by perennial ryegrass (Lolium perenne L.). White clover (Trifolium repens) and broad-leaved docks (Rumex obtusifolius) were present in low amounts (clover $<2 \%$ ), and, in order to prevent any confounding effect of clover, the sward was sprayed using an appropriate herbicide one month prior to each treatment application. The long-term (1995-2010) average rainfall and daily temperature for the site were $916 \mathrm{~mm}$ and $9.3^{\circ} \mathrm{C}$, respectively. The soil is a sandy clay loam with moderate drainage. The site was managed as a low $\mathrm{N}$ input system to maintain the same sward for all experiments. A basal dressing of $\mathrm{P}, \mathrm{K}$ and $\mathrm{S}$ was applied prior to each experiment so that these major nutrients were not limiting grass growth. 
Table 1. Properties and application rates of the cattle slurries.

\begin{tabular}{|c|c|c|c|c|c|c|c|c|c|c|c|c|c|c|c|c|}
\hline \multirow[b]{2}{*}{ Application Date } & \multicolumn{12}{|c|}{ Raw CS properties } & \multicolumn{4}{|c|}{ Amended CS properties } \\
\hline & $\begin{array}{l}\mathrm{NH}_{4}^{+}-\mathrm{N} \\
\mathrm{mg} \mathrm{kg}^{-1}\end{array}$ & $\begin{array}{r}\text { Acetic } \\
\text { Acid } \\
\mathrm{g} \mathrm{L}^{-1}\end{array}$ & $\begin{array}{r}\text { Ethanol } \\
\mathrm{gL}^{-1}\end{array}$ & $\begin{array}{r}\text { i-Butyric } \\
\text { Acid } \\
\mathrm{gL}^{-1}\end{array}$ & $\begin{array}{r}\text { i-Valeric } \\
\text { Acid } \\
\mathrm{gL}^{-1}\end{array}$ & $\begin{array}{r}\text { Lactic } \\
\text { Acid } \\
\mathrm{gL}^{-1}\end{array}$ & $\begin{array}{r}\text { n-Butyric } \\
\text { Acid } \\
\mathrm{gL}^{-1}\end{array}$ & $\begin{array}{r}\mathrm{n} \text {-Valeric } \\
\text { Acid } \\
\mathrm{g} \mathrm{L}^{-1}\end{array}$ & $\begin{array}{l}\text { Propanol } \\
\qquad \mathrm{gL}^{-1}\end{array}$ & $\begin{array}{r}\text { Propionic } \\
\text { Acid } \\
\mathrm{gL}^{-1}\end{array}$ & $\begin{array}{r}\text { Total } \\
\text { VFAs } \\
\mathrm{g} \mathrm{L}^{-1}\end{array}$ & $\begin{array}{c}\text { Dumas C } \\
\mathrm{g} \mathrm{kg}^{-1} \\
\text { dry matter }\end{array}$ & $\mathrm{pH}$ & $\begin{array}{r}\text { Dry } \\
\text { Matter } \\
\%\end{array}$ & $\begin{array}{r}\mathrm{NH}_{4}^{+}-\mathrm{N} \\
\text { rate } \\
\mathrm{kg} \mathrm{Nha}^{-1}\end{array}$ & $\begin{array}{r}\mathrm{NO}_{3}^{-}-\mathrm{N} \\
\text { rate } \\
\mathrm{kg} \mathrm{Nha}^{-1}\end{array}$ \\
\hline Mar-09 & 2845 & 5.54 & 0.00 & 0.16 & 0.30 & 0.00 & 0.14 & 0.00 & 0.00 & 1.66 & 7.80 & 409.9 & 7.88 & 5.00 & 135.1 & 65 \\
\hline Jun-09 & 2001 & 7.98 & 0.00 & 0.26 & 0.38 & 0.00 & 0.88 & 0.14 & 0.00 & 2.72 & 12.36 & 430.2 & 7.88 & 5.00 & 82.7 & 65 \\
\hline Oct-09 & 1545 & 5.74 & 0.00 & 0.18 & 0.34 & 0.00 & 0.36 & 0.00 & 0.00 & 1.70 & 8.32 & 370.2 & 7.40 & 3.79 & 103.4 & 65 \\
\hline Mar-10 & 1960 & 3.99 & 0.00 & 0.07 & 0.17 & 0.00 & 0.16 & 0.00 & 0.00 & 0.51 & 4.90 & 415.8 & 8.27 & 5.02 & 140.6 & 65 \\
\hline Jun-10 & 1671 & 4.28 & 0.00 & 0.12 & 0.20 & 0.00 & 0.46 & 0.00 & 0.00 & 1.06 & 6.12 & 421.3 & 7.14 & 5.39 & 114.7 & 65 \\
\hline Oct-10 & 1068 & 2.14 & 0.10 & 0.00 & 0.14 & 0.00 & 0.08 & 0.00 & 0.00 & 0.08 & 2.54 & 393.7 & 7.52 & 3.16 & 80.0 & 65 \\
\hline Mar-11 & 2485 & 5.18 & 0.00 & 0.16 & 0.30 & 0.00 & 0.50 & 0.06 & 0.00 & 1.42 & 7.62 & 424.9 & 7.43 & 5.00 & 73.9 & 65 \\
\hline
\end{tabular}

\subsection{Experimental treatments}

Cattle slurry $\left(33 \mathrm{~m}^{3} \mathrm{ha}^{-1}\right)$ amended with $\mathrm{KNO}_{3}$ $\left(65 \mathrm{~kg} \mathrm{Nha}^{-1}\right)$, with or without DCD (at $15 \% \mathrm{NH}_{4}^{+}-\mathrm{N}$ content of the CS), was surface applied to grassland with either the $\mathrm{NH}_{4}^{+}$or the $\mathrm{NO}_{3}^{-}$pool ${ }^{15} \mathrm{~N}$ labelled $\left({ }^{15} \mathrm{CS}^{14} \mathrm{NO}_{3}\right.$, ${ }^{14} \mathrm{CS}^{15} \mathrm{NO}_{3}$ ) at 50 atom \%, according to the procedure of Stevens et al. (1997). Ammonium chloride $\left(\mathrm{NH}_{4} \mathrm{Cl}\right)$ amended with $\mathrm{KNO}_{3}\left(65 \mathrm{~kg} \mathrm{Nha}^{-1}\right)$, with or without DCD, with either the $\mathrm{NH}_{4}^{+}$or the $\mathrm{NO}_{3}^{-}$pool ${ }^{15} \mathrm{~N}$ labelled, served as controls for ${ }^{14} \mathrm{CS}^{15} \mathrm{NO}_{3}$ and ${ }^{15} \mathrm{CS}^{14} \mathrm{NO}_{3}$, respectively, having the same amount of $\mathrm{NH}_{4}^{+}-\mathrm{N}$ as the $\mathrm{CS}$ but no degradable carbon. In summary, there were eight treatments: (i) ${ }^{15} \mathrm{CS}^{14} \mathrm{NO}_{3}$ without $\mathrm{DCD}$, (ii) ${ }^{15} \mathrm{CS}^{14} \mathrm{NO}_{3}$ with $\mathrm{DCD}$, (iii) ${ }^{14} \mathrm{CS}^{15} \mathrm{NO}_{3}$ without $\mathrm{DCD}$, (iv) ${ }^{14} \mathrm{CS}^{15} \mathrm{NO}_{3}$ with $\mathrm{DCD}$, (v) ${ }^{15} \mathrm{NH}_{4} \mathrm{Cl}^{14} \mathrm{NO}_{3}$ without $\mathrm{DCD}$, (vi) ${ }^{15} \mathrm{NH}_{4} \mathrm{Cl}^{14} \mathrm{NO}_{3}$ with $\mathrm{DCD}$, (vii) ${ }^{14} \mathrm{NH}_{4} \mathrm{Cl}^{15} \mathrm{NO}_{3}$ without $\mathrm{DCD}$, and (viii) ${ }^{14} \mathrm{NH}_{4} \mathrm{Cl}^{15} \mathrm{NO}_{3}$ with DCD. The eight treatments were replicated four times in a randomised block design. Immediately prior to application aliquots of $\mathrm{CS} / \mathrm{NH}_{4} \mathrm{Cl}, \mathrm{KNO}_{3}$, and $\mathrm{DCD} /$ water were mixed together and uniformly applied directly inside the chamber (area of $0.16 \mathrm{~m}^{2}$ ).

\subsection{Slurry collection and analysis}

Dairy CS was collected prior to each of the seven treatment application dates. The properties of the raw and amended CS and application rates for each of the seven application dates are detailed in Table 1. CS was amended by adding either unlabelled urea or urea enriched at 99 atom \% and incubating the $\mathrm{CS}$ for 3 days at $35^{\circ} \mathrm{C}$ to hydrolyse the urea to $\mathrm{NH}_{4}^{+}$N (Stevens and Laughlin, 2001a). Slurry dry matter content was determined by drying a representative slurry sample at $105^{\circ} \mathrm{C}$ for $24 \mathrm{~h}$. Total ammoniacal $\mathrm{N}$ in slurry was determined by steam distillation into boric acid solution, in the presence of magnesium oxide. The boric acid solution was titrated with $0.1 \mathrm{M}$ sulphuric acid to determine the ammonium $\mathrm{N}$ in the sample. Slurry $\mathrm{pH}$ was determined by Orion pH meter Model 420A; volatile fatty acids (VFAs) by capillary gas-liquid chromatography and detected by a flame ionization detector; and total $\mathrm{C}$ by the Dumas method (Bremner and Mulvaney, 1984) with quantitative analysis by an Elementar Vario Max CN elemental analyser.

\subsection{Flux measurement technique}

Gaseous $\mathrm{N}_{2}$ and $\mathrm{N}_{2} \mathrm{O}$ emissions were measured using the static chamber method by deploying square stainless steel chambers $(0.4 \times 0.4 \mathrm{~m}$ wide and $0.15 \mathrm{~m}$ high). The chamber collar was inserted into the ground to a depth of $\geq 5 \mathrm{~cm}$ at least 3 days prior to commencing each experiment, and left in position for the duration of the experiment. The collars had a water-filled trough into which the chamber lid was placed when sampling, thus ensuring a gas-tight seal. Gas sampling occurred between 10:00 and 12:00 GMT on $10 \mathrm{oc}-$ casions over a 20-day period following treatment application. In order to detect evolved ${ }^{15} \mathrm{~N}_{2}$, Stevens and Laughlin (1998) showed that a chamber closure time of $2 \mathrm{~h}$ was necessary. After $2 \mathrm{~h}$, samples of the chamber headspace were taken through a silicone septa positioned on the centre of the chamber lid, using a $20-\mathrm{mL}$ polypropylene syringe equipped with a 25 -gauge luer lock needle $(0.5 \times 16 \mathrm{~mm})$. The syringe was flushed once with headspace air before sampling. A 15$\mathrm{mL}$ sample was withdrawn from the chamber and injected into a $12-\mathrm{mL}$ pre-evacuated glass vials fitted with a $3-\mathrm{mm}$ butyl rubber septa (Labco, UK). Linearity checks on $\mathrm{N}_{2} \mathrm{O}$ were conducted on 104 occasions over the total experimental period from the $\mathrm{CSNO}_{3}$ without DCD treatment by sampling the chamber headspace four times over the chamber closure period. Chamber datasets were not examined for linearity if the $T_{2} \mathrm{~h}$ sample was not significantly higher than the $T_{0 \mathrm{~h}}$ sample, or occasionally if apparent leaks occurred in the vials. From the 104 chamber datasets, $27 \%$ were discarded for these reasons. In Fig. 1 the percentage of data is depicted for ranges of linear coefficient of determination $\left(R^{2}\right)$ for the accepted datasets. Eighty-four percent of the accepted data had an $R^{2}$ of $>0.85$. As this experiment was a comparative study, it was deemed suitable to apply a linear regression model to all data. Cumulative fluxes were calculated by linear interpolation between sampling times.

\subsection{Analysis of $\mathrm{N}_{2} \mathrm{O}$ and $\mathrm{N}_{2}$}

The concentration and ${ }^{15} \mathrm{~N}$ content of $\mathrm{N}_{2} \mathrm{O}$ and the ${ }^{15} \mathrm{~N}$ content of the $\mathrm{N}_{2}$ was determined by automated isotope ratio mass spectrometry (IRMS) as described by Stevens et al. (1993), using a Europa Scientific 20-20 stable isotope 


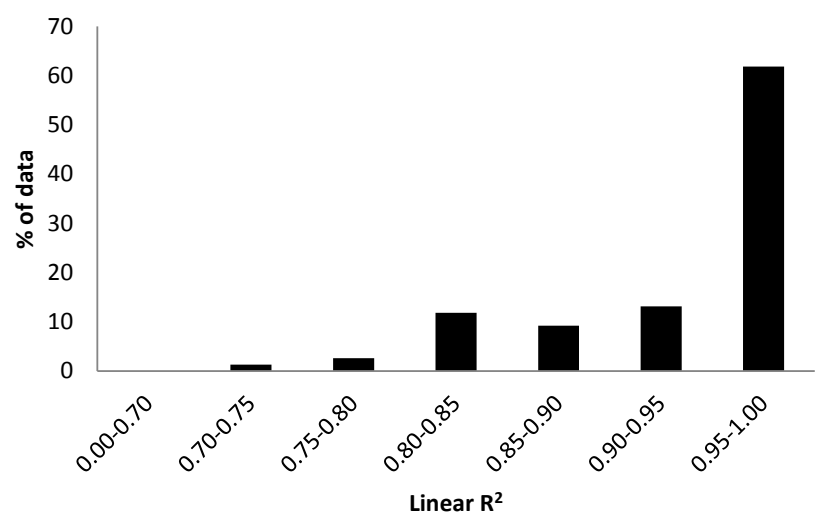

Fig. 1. Percentage of data for given ranges of coefficient of determination $\left(R^{2}\right)$ of the linear regression, $n=76$.

analyser interfaced to a Europa Scientific Trace Gas Preparation System ANCA-TG (Crewe, UK) with Gilson autosampler (Anachem, Luton, UK). The ion currents (I) at mass-tocharge ratio $(m / z) 44,45$, and 46 enabled concentrations and molecular ratios ${ }^{45} \mathrm{R}\left({ }^{45} \mathrm{I} /{ }^{44} \mathrm{I}\right)$ and ${ }^{46} \mathrm{R}\left({ }^{46} \mathrm{I} /{ }^{44} \mathrm{I}\right)$ to be calculated for $\mathrm{N}_{2} \mathrm{O}$. The sources of $\mathrm{N}_{2} \mathrm{O}$ were then apportioned into the fraction $\left(d_{\mathrm{D}}^{\prime}\right)$ derived from the denitrifying pool of enrichment $a_{\mathrm{D}}$ and the fraction $d_{\mathrm{N}}^{\prime}=\left(1-d_{\mathrm{D}}^{\prime}\right)$ derived from the pool or pools at natural abundance (Arah, 1997). For $\mathrm{N}_{2}$, the ion currents at $m / z 28,29$ and 30 enabled molecular ratios ${ }^{29} \mathrm{R}\left({ }^{29} \mathrm{I} /{ }^{28} \mathrm{I}\right)$ and ${ }^{30} \mathrm{R}\left({ }^{30} \mathrm{I} /{ }^{28} \mathrm{I}\right)$ to be determined. Differences between the molecular ratios in enriched and normal atmospheres were calculated as $\Delta^{29} \mathrm{R}$ and $\Delta^{30} \mathrm{R}$. The flux of $\mathrm{N}_{2}$ was calculated using $\Delta^{30} \mathrm{R}$ data only and the equation of Mulvaney (1984), assuming that the enrichment of the denitrifying pool was $a_{\mathrm{D}}$ (Stevens and Laughlin, 2001b). This method of $\mathrm{N}_{2}$ flux calculation improved the sensitivity of $\mathrm{N}_{2}$ emission measurement by a factor of 16 , and without this method we could not have detected the $\mathrm{N}_{2}$ flux.

\subsection{Statistical methods}

Analyses were carried out using GenStat version 14 software. Each of the seven application times was analysed separately. The experiment was analysed using analysis of variance as a randomised block experiment with a full factorial design incorporating two factors. The factors used were $\mathrm{NH}_{4}^{+}-\mathrm{N}$ form (two levels: $\mathrm{CS}$ or $\mathrm{NH}_{4} \mathrm{Cl}$ ) and DCD (2 levels: with and without DCD). The ANOVA model was used to ascertain the significance of treatments on the cumulative fluxes of $\mathrm{N}_{2} \mathrm{O}, \mathrm{N}_{2}$, and $\mathrm{N}_{2} \mathrm{O}$ mole fraction, and on the values of $d_{\mathrm{D}}^{\prime}$ and $a_{\mathrm{D}}$. A significance level of 0.05 was used, unless otherwise stated. Estimates of means, standard error of means, standard error of differences in means and Fisher's least significant difference (LSD) were calculated.

\section{Results}

\subsection{Composition of applied cattle slurries}

The $\mathrm{NH}_{4}^{+}-\mathrm{N}$ contents of the amended slurries used over the course of this experiment varied considerably over the seven application times (Table 1). The rate of $\mathrm{NH}_{4}^{+}-\mathrm{N}$ applied varied between 73.9 to $140.6 \mathrm{~kg} \mathrm{~N}^{-1}$. The same rate of $\mathrm{NO}_{3}^{-}-\mathrm{N}$ was applied on each occasion to give a rate of $65 \mathrm{~kg} \mathrm{Nha}^{-1}$. The slurries used had a mean dry matter content of $4.6 \%$, and the $\mathrm{pH}$ ranged from 7.14 to 8.27 (Table 1).

\subsection{Rainfall and soil temperature}

Daily rainfall and soil temperature at $5 \mathrm{~cm}$ were collected at a weather station located within $1 \mathrm{~km}$ of the site. Figure 2 shows the daily data for 20 days post-treatment application for each of the seven application times. The total rainfall for five days post-application ranged from $0.0 \mathrm{~mm}$ in June 2010 to $33.0 \mathrm{~mm}$ in July 2009 , indicating a wide range of rainfall conditions.

\subsection{Overview of chamber fluxes}

The $\mathrm{N}_{2} \mathrm{O}$ and $\mathrm{N}_{2}$ emitted over each measurement period showed a similar pattern, with peak emissions occurring in the first five days after treatment application. Figure 3 illustrates a typical pattern of emissions for July 2009 for $\mathrm{N}_{2}$ and $\mathrm{N}_{2} \mathrm{O}$. On each of the seven application times, $\mathrm{N}_{2} \mathrm{O}$ fluxes were higher for the $\mathrm{CSNO}_{3}$ treatment than the $\mathrm{NH}_{4} \mathrm{ClNO}_{3}$ treatment. Fluxes were considerably lower in June 2010 compared to other measurement periods, probably due to lower soil moisture contents, as there was no rainfall for 10 days post-treatment application.

\subsection{Cumulative emissions}

The cumulative fluxes of $\mathrm{N}_{2} \mathrm{O}-\mathrm{N}$ and $\mathrm{N}_{2}-\mathrm{N}$ and the mole fraction of $\mathrm{N}_{2} \mathrm{O}\left(\mathrm{N}_{2} \mathrm{O} /\left(\mathrm{N}_{2} \mathrm{O}+\mathrm{N}_{2}\right)\right)$ for each measurement period are given in Table 2. The flux of $\mathrm{N}_{2} \mathrm{O}$ was independent of the ${ }^{15} \mathrm{~N}$ labelling; therefore, fluxes from treatments with either the $\mathrm{NH}_{4}^{+}$or the $\mathrm{NO}_{3}^{-}$pool ${ }^{15} \mathrm{~N}$ labelled (e.g. ${ }^{15} \mathrm{CS}^{14} \mathrm{NO}_{3}$ and ${ }^{14} \mathrm{CS}^{15} \mathrm{NO}_{3}$ ) were averaged. It was only possible to measure the flux of $\mathrm{N}_{2}$ from treatments where the ${ }^{15} \mathrm{NO}_{3}$ pool was labelled.

Cumulative $\mathrm{N}_{2} \mathrm{O}$ emissions over 20 days in the $\mathrm{CSNO}_{3}$ without DCD treatment ranged from $0.76 \mathrm{~kg} \mathrm{Nha}^{-1}$ in June 2010 to $17.28 \mathrm{~kg} \mathrm{Nha}^{-1}$ in March 2009; $\mathrm{CSNO}_{3}$ with DCD treatment ranged from $0.88 \mathrm{~kg} \mathrm{Nha}^{-1}$ in June 2010 to $12.79 \mathrm{~kg} \mathrm{Nha}^{-1}$ in March 2009; $\mathrm{NH}_{4} \mathrm{ClNO}_{3}$ without DCD treatment ranged from $0.51 \mathrm{~kg} \mathrm{Nha}^{-1}$ in June 2010 to $8.79 \mathrm{~kg} \mathrm{Nha}^{-1}$ in March 2009; and in the $\mathrm{NH}_{4} \mathrm{ClNO}_{3}$ with DCD treatment cumulative $\mathrm{N}_{2} \mathrm{O}$ emissions ranged from $0.47 \mathrm{~kg} \mathrm{Nha}^{-1}$ in June 2010 to $6.70 \mathrm{~kg} \mathrm{Nha}^{-1}$ in March 2009. 
Table 2. Cumulative fluxes of $\mathrm{N}_{2} \mathrm{O}$ and $\mathrm{N}_{2}$ evolved over 20 days after treatment application for $\mathrm{CSNO}_{3}$ and $\mathrm{NH}_{4} \mathrm{ClNO}_{3}$ with and without DCD.

\begin{tabular}{|c|c|c|c|c|c|c|c|c|c|c|c|c|}
\hline \multirow[b]{2}{*}{$\begin{array}{l}\text { Application } \\
\text { Date }\end{array}$} & \multirow[b]{2}{*}{ Treatment } & \multicolumn{3}{|c|}{$\begin{array}{c}\mathrm{N}_{2} \mathrm{O} \\
\left(\mathrm{kg} \mathrm{Nha}^{-1}\right)\end{array}$} & \multicolumn{3}{|c|}{$\begin{array}{c}\mathrm{N}_{2} \\
\left(\mathrm{~kg} \mathrm{Nha}^{-1}\right)\end{array}$} & \multicolumn{3}{|c|}{$\begin{array}{l}\mathrm{N}_{2} \mathrm{O} \text { mole fraction } \\
\left(\mathrm{N}_{2} \mathrm{O} /\left(\mathrm{N}_{2} \mathrm{O}+\mathrm{N}_{2}\right)\right)\end{array}$} & \multirow{2}{*}{$\begin{array}{l}\text { Rainfall } 5 \text { days } \\
\text { post- } \\
\text { application } \\
(\mathrm{mm})\end{array}$} & \multirow{2}{*}{$\begin{array}{l}\text { Temperature } \\
\text { average } \\
\text { over } 20 \text { days } \\
\left({ }^{\circ} \mathrm{C}\right)\end{array}$} \\
\hline & & $\begin{array}{r}\text { without } \\
\text { DCD }\end{array}$ & $\begin{array}{l}\text { with } \\
\text { DCD }\end{array}$ & Signif. & $\begin{array}{r}\text { without } \\
\text { DCD }\end{array}$ & $\begin{array}{l}\text { with } \\
\text { DCD }\end{array}$ & Signif. & $\begin{array}{r}\text { without } \\
\text { DCD }\end{array}$ & $\begin{array}{l}\text { with } \\
\text { DCD }\end{array}$ & Signif. & & \\
\hline \multirow{2}{*}{ Mar-09 } & $\mathrm{CSNO}_{3}$ & 17.28 & 12.79 & $* *$ & 42.38 & 21.77 & ** & 0.28 & 0.36 & $* *$ & \multirow{2}{*}{7.1} & \multirow{2}{*}{7.8} \\
\hline & $\mathrm{NH}_{4} \mathrm{ClNO}_{3}$ & 8.79 & 6.70 & NS & 34.92 & 14.54 & * & 0.19 & 0.31 & $* *$ & & \\
\hline \multirow{2}{*}{ Jul-09 } & $\mathrm{CSNO}_{3}$ & 12.91 & 12.73 & NS & 34.27 & 19.83 & NS & 0.29 & 0.38 & NS & \multirow{2}{*}{30.0} & \multirow{2}{*}{15.3} \\
\hline & $\mathrm{NH}_{4} \mathrm{ClNO}_{3}$ & 6.12 & 4.43 & NS & 30.11 & 18.19 & NS & 0.19 & 0.19 & NS & & \\
\hline \multirow{2}{*}{ Oct-09 } & $\mathrm{CSNO}_{3}$ & 6.09 & 6.54 & NS & 10.42 & 14.97 & NS & 0.36 & 0.32 & NS & \multirow[b]{2}{*}{33.0} & \multirow[b]{2}{*}{8.2} \\
\hline & $\mathrm{NH}_{4} \mathrm{ClNO}_{3}$ & 4.18 & 5.15 & NS & 11.10 & 9.67 & NS & 0.29 & 0.36 & NS & & \\
\hline \multirow{2}{*}{ Mar-10 } & $\mathrm{CSNO}_{3}$ & 9.71 & 9.01 & NS & 23.91 & 21.52 & NS & 0.30 & 0.29 & NS & \multirow{2}{*}{19.4} & \multirow{2}{*}{5.6} \\
\hline & $\mathrm{NH}_{4} \mathrm{ClNO}_{3}$ & 4.49 & 3.98 & NS & 21.35 & 16.99 & NS & 0.16 & 0.19 & NS & & \\
\hline \multirow{2}{*}{ Jun-10 } & $\mathrm{CSNO}_{3}$ & 0.76 & 0.88 & NS & 3.77 & 3.43 & NS & 0.17 & 0.21 & NS & \multirow{2}{*}{0.0} & \multirow{2}{*}{15.4} \\
\hline & $\mathrm{NH}_{4} \mathrm{ClNO}_{3}$ & 0.51 & 0.47 & NS & 3.03 & 3.08 & NS & 0.15 & 0.13 & NS & & \\
\hline \multirow{2}{*}{ Oct-10 } & $\mathrm{CSNO}_{3}$ & 8.60 & 6.60 & NS & 13.55 & 8.47 & NS & 0.39 & 0.44 & NS & \multirow{2}{*}{1.0} & \multirow{2}{*}{9.3} \\
\hline & $\mathrm{NH}_{4} \mathrm{ClNO}_{3}$ & 6.52 & 4.26 & NS & 12.23 & 9.49 & NS & 0.36 & 0.33 & NS & & \\
\hline \multirow{2}{*}{ Mar-11 } & $\mathrm{CSNO}_{3}$ & 2.98 & 4.85 & NS & 3.27 & 4.32 & NS & 0.46 & 0.50 & NS & \multirow{2}{*}{5.5} & \multirow{2}{*}{10.1} \\
\hline & $\mathrm{NH}_{4} \mathrm{ClNO}_{3}$ & 1.18 & 0.70 & & 2.47 & 1.32 & & 0.33 & 0.24 & & & \\
\hline
\end{tabular}

Significance levels: ${ }^{* * *} P<0.001,{ }^{* *} P<0.01,{ }^{*} P<0.05, \mathrm{NS}=$ no significant difference.

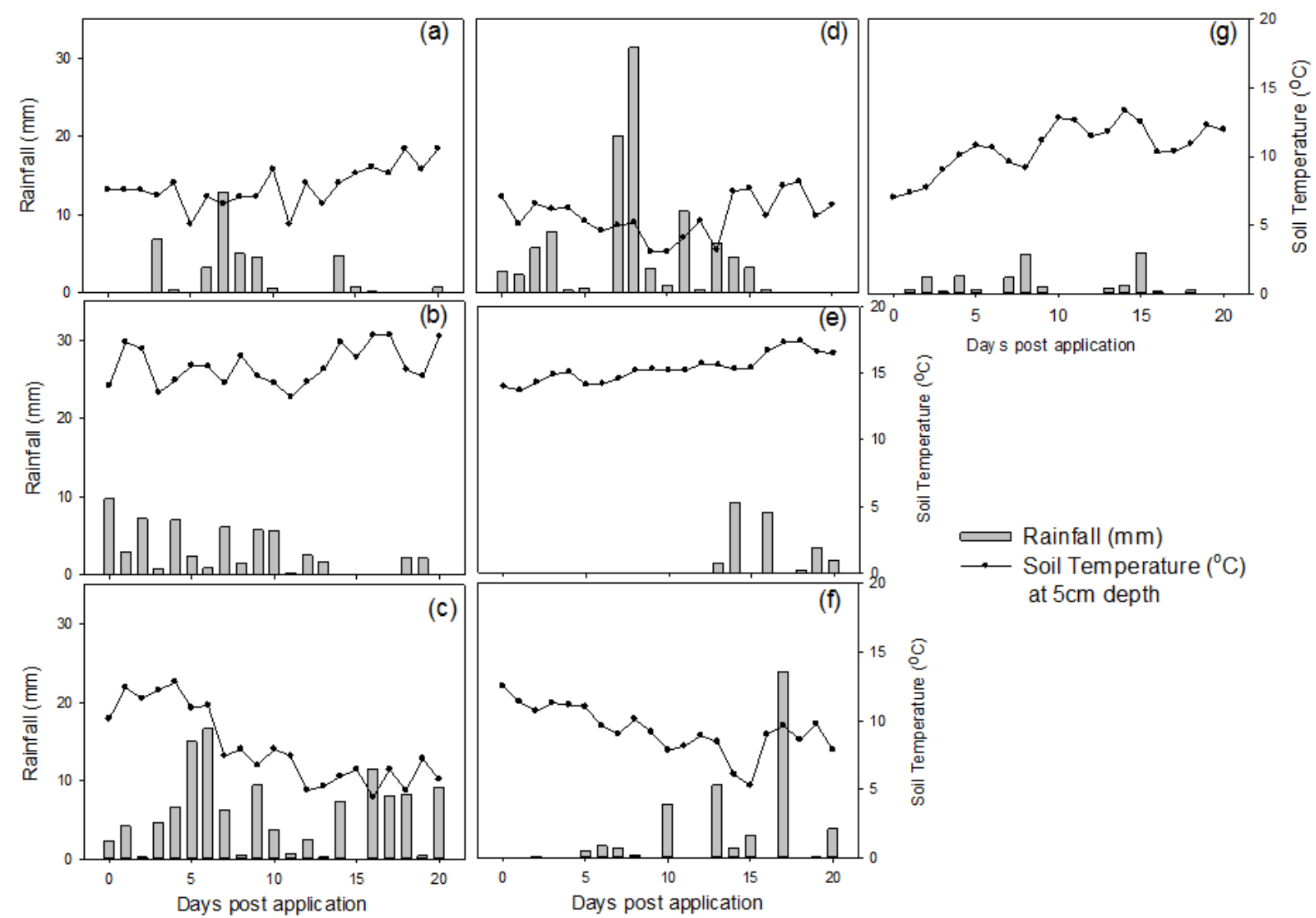

Fig. 2. Rainfall and Soil Temperature at $5 \mathrm{~cm}$ depth for 20 days post-treatment application for (a) March 2009, (b) July 2009, (c) October 2009, (d) March 2010, (e) June 2010, (f) October 2010, and (g) March 2011. 


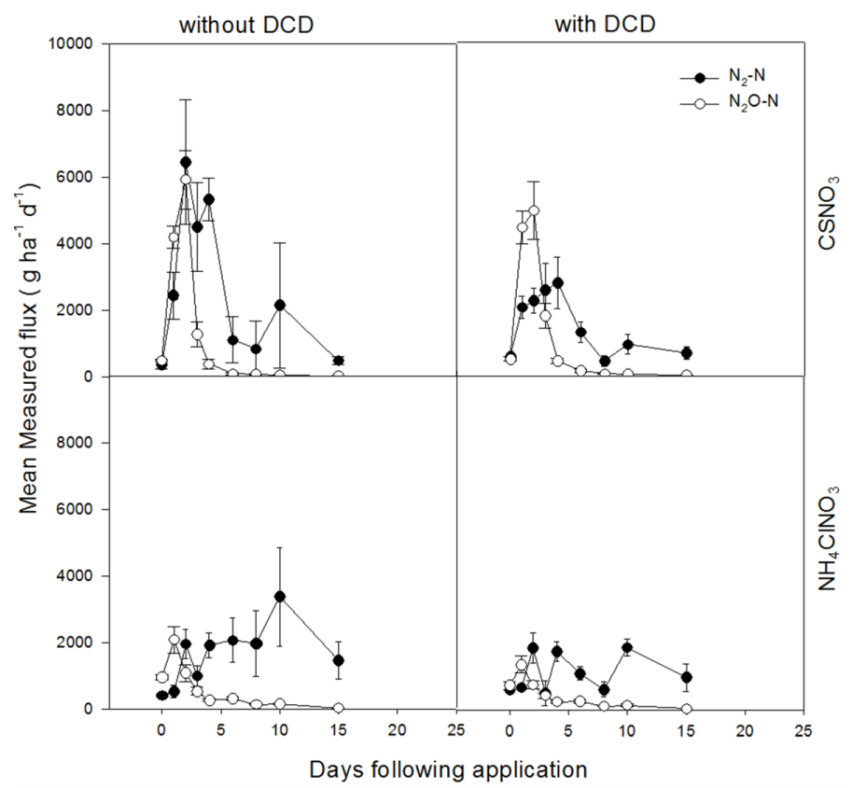

Fig. 3. Mean measured $\mathrm{N}_{2} \mathrm{O}-\mathrm{N}$ and $\mathrm{N}_{2}-\mathrm{N}$ fluxes versus time for $\mathrm{CSNO}_{3}$ and $\mathrm{NH}_{4} \mathrm{ClNO}_{3}$ with and without DCD for July 2009.

Cumulative $\mathrm{N}_{2}$ emissions over 20 days in the $\mathrm{CSNO}_{3}$ without DCD treatment ranged from $3.27 \mathrm{~kg} \mathrm{Nha}^{-1}$ in March 2011 to $42.38 \mathrm{~kg} \mathrm{~N} \mathrm{ha}^{-1}$ in March 2009; $\mathrm{CSNO}_{3}$ with DCD treatment ranged from $3.43 \mathrm{~kg} \mathrm{Nha}^{-1}$ in June 2010 to $21.77 \mathrm{~kg} \mathrm{Nha}^{-1}$ in March 2009; $\mathrm{NH}_{4} \mathrm{ClNO}_{3}$ without DCD treatment ranged from $3.03 \mathrm{~kg} \mathrm{Nha}^{-1}$ in June 2010 to $34.92 \mathrm{~kg} \mathrm{Nha}^{-1}$ in March 2009; and in the $\mathrm{NH}_{4} \mathrm{ClNO}_{3}$ with DCD treatment cumulative $\mathrm{N}_{2}$ emissions ranged from $1.32 \mathrm{~kg} \mathrm{Nha}^{-1}$ in March 2011 to $18.19 \mathrm{~kg} \mathrm{Nha}^{-1}$ in July 2009.

\subsubsection{Effect of $\mathrm{CS}$ on the cumulative emissions of $\mathrm{N}_{2} \mathrm{O}$ and $\mathrm{N}_{2}$}

On each of the seven application times, the presence of CS significantly increased cumulative $\mathrm{N}_{2} \mathrm{O}$ emissions (when compared to the $\mathrm{NH}_{4} \mathrm{Cl}$ control) on all occasions (March 2009, $P<0.001$; July 2009, $P<0.001$; October 2009, $P<0.01$; March 2010, $P<0.001$; June 2010, $P<0.001$; October 2010, $P<0.05$; March 2011, $P<0.001)$. This increase ranged from a factor of between 1.27 and 6.93 .

The presence of CS significantly increased cumulative $\mathrm{N}_{2}$ emissions on only two occasions: in March $2009(P<0.05)$ and in March $2011(P<0.01)$.

When CS was applied, the $\mathrm{N}_{2} \mathrm{O}$ mole fraction $\left(\mathrm{N}_{2} \mathrm{O} /\left(\mathrm{N}_{2} \mathrm{O}+\mathrm{N}_{2}\right)\right)$ increased on all occasions. The $\mathrm{N}_{2} \mathrm{O}$ mole fraction averaged over the seven measurement periods, was significantly higher $(P<0.001)$ for $\mathrm{CSNO}_{3}$ at 0.34 ( \pm 0.03 standard error) compared to $\mathrm{NH}_{4} \mathrm{ClNO}_{3}$ at 0.24 ( \pm 0.03 standard error). The average $\mathrm{N}_{2} \mathrm{O}$ mole fraction was lower (0.19) in June 2010, under relatively dry conditions, than at other times (average 0.34) (Table 2).

\subsubsection{Effect of DCD on the cumulative emissions of $\mathrm{N}_{2} \mathrm{O}$ and $\mathrm{N}_{2}$}

When data were averaged over the $\mathrm{CSNO}_{3}$ and $\mathrm{NH}_{4} \mathrm{ClNO}_{3}$ treatments, there was an overall DCD effect on two occasions, where the application of DCD was shown to decrease cumulative $\mathrm{N}_{2} \mathrm{O}$ emission in March $2010(P<0.001)$ and October $2010(P<0.05)$ (results not shown). When the DCD effect on $\mathrm{CSNO}_{3}$ was examined, there was a significant decrease $(P<0.01)$ in cumulative $\mathrm{N}_{2} \mathrm{O}$ emissions in March 2009 from 17.28 to $12.79 \mathrm{~kg} \mathrm{~N} \mathrm{ha}^{-1}$. However, DCD did not significantly decrease $\mathrm{N}_{2} \mathrm{O}$ emissions in $\mathrm{CSNO}_{3}$ at any other time. There was a significant decrease $(P<0.05)$ in cumulative $\mathrm{N}_{2} \mathrm{O}$ emissions from $\mathrm{NH}_{4} \mathrm{ClNO}_{3}$ in March 2011 from 1.18 to $0.70 \mathrm{~kg} \mathrm{~N} \mathrm{ha}^{-1}$, but DCD did not significantly decrease $\mathrm{N}_{2} \mathrm{O}$ emissions at any other time.

Across all treatments there was a decrease in $\mathrm{N}_{2}$ cumulative emissions in March $2009(P<0.001)$, July 2009 $(P<0.01)$, and October $2010(P<0.05)$. There was a significant decrease $(P<0.001)$ in $\mathrm{N}_{2}$ emissions from $\mathrm{CSNO}_{3}$ in March 2009, where the cumulative $\mathrm{N}_{2}$ emission decreased from 42.38 to $21.77 \mathrm{~kg} \mathrm{Nha}^{-1}$ (Table 2). DCD did not significantly decrease $\mathrm{N}_{2}$ emission in $\mathrm{CSNO}_{3}$ on any other occasion. There was a significant decrease in $\mathrm{N}_{2}$ emissions from $\mathrm{NH}_{4} \mathrm{ClNO}_{3}$ in March 2009 and March 2011 from 34.92 to $14.54 \mathrm{~kg} \mathrm{Nha}^{-1}$ and from 2.47 to $1.32 \mathrm{~kg} \mathrm{~N} \mathrm{ha}^{-1}$, respectively; DCD did not significantly decrease $\mathrm{N}_{2}$ emissions in $\mathrm{NH}_{4} \mathrm{ClNO}_{3}$ at any other time (Table 2).

DCD significantly increased the $\mathrm{N}_{2} \mathrm{O}$ mole fraction $\left(\mathrm{N}_{2} \mathrm{O} / \mathrm{N}_{2} \mathrm{O}+\mathrm{N}_{2}\right)$ in March 2009, but had no significant effect at other times.

\section{Source of $\mathrm{N}_{2} \mathrm{O}$}

Following the procedure of Arah (1997), the fraction $\left(d_{\mathrm{D}}^{\prime}\right)$ of the $\mathrm{N}_{2} \mathrm{O}$ flux that was derived from the ${ }^{15} \mathrm{NO}_{3}$ pool and the ${ }^{15} \mathrm{~N}$ atom fraction $\left(a_{\mathrm{D}}\right)$ of that pool were calculated. Values of $a_{\mathrm{D}}$ indicate the enrichment of the ${ }^{15} \mathrm{~N}$-labelled denitrifying pool, and its change over time is indicative of the rate of nitrification. Calculations of $d_{\mathrm{D}}^{\prime}$ and $a_{\mathrm{D}}$ can only be performed when the nitrate pool is labelled and when there is a detectable $\mathrm{N}_{2} \mathrm{O}$ flux. Therefore only values obtained from the ${ }^{14} \mathrm{CS}^{15} \mathrm{NO}_{3}$ and ${ }^{14} \mathrm{NH}_{4} \mathrm{Cl}^{15} \mathrm{NO}_{3}$ treatments are presented. As the $\mathrm{N}_{2} \mathrm{O}$ peak emission pattern was different for each application event, $\mathrm{N}_{2} \mathrm{O} a_{\mathrm{D}}$ values, when the $\mathrm{N}_{2} \mathrm{O}$ flux was above 2 ppmv, and $\mathrm{N}_{2} \mathrm{O} d_{\mathrm{D}}$ values are given at times of maximum peak $\mathrm{N}_{2} \mathrm{O}$ emissions. Values of $a_{\mathrm{D}}$ are presented in Table 3 for ${ }^{14} \mathrm{CS}^{15} \mathrm{NO}_{3}$ and ${ }^{14} \mathrm{NH}_{4} \mathrm{Cl}^{15} \mathrm{NO}_{3}$ with and without DCD.

$\mathrm{N}_{2} \mathrm{O} \quad a_{\mathrm{D}}$ value at the first sampling time after application (after approximately $2 \mathrm{~h}$ ) was 0.50 , which was the 
Table 3. The fraction of the ${ }^{15} \mathrm{~N}$-labelled nitrate pool $\left(a_{\mathrm{D}}\right)$ for $\mathrm{CSNO}_{3}$ and $\mathrm{NH}_{4} \mathrm{ClNO}_{3}$ with and without DCD.

\begin{tabular}{lrrrrrrr}
\hline & Mar-09 & Jul-09 & Oct-09 & Mar-10 & Jun-10 & Oct-10 & Mar-11 \\
\hline $\begin{array}{l}\text { Time to reach minimum } \\
\text { detectable flux (days) }\end{array}$ & 10 & 4 & 3 & 10 & 3 & 11 & 11 \\
\hline $\mathrm{CSNO}_{3}$ without DCD & 0.37 & 0.47 & 0.51 & 0.46 & 0.45 & 0.36 & 0.38 \\
$\mathrm{CSNO}_{3}$ with DCD & 0.47 & 0.48 & 0.48 & 0.50 & 0.49 & 0.44 & 0.44 \\
$\mathrm{NH}_{4} \mathrm{ClNO}_{3}$ without DCD & 0.25 & 0.40 & 0.42 & 0.36 & 0.43 & 0.33 & 0.30 \\
$\mathrm{NH}_{4} \mathrm{ClNO}_{3}$ with DCD & 0.45 & 0.43 & 0.44 & 0.47 & 0.48 & 0.39 & 0.39 \\
\hline $\mathrm{CSNO}_{3}$ vs. $\mathrm{NH}_{4} \mathrm{ClNO}_{3}$ & $<0.001$ & $<0.01$ & $<0.01$ & $<0.001$ & $<0.01$ & $\mathrm{NS}$ & $<0.001$ \\
DCD effect on CSNO$_{3}$ & $<0.001$ & $\mathrm{NS}$ & $\mathrm{NS}$ & $<0.05$ & $<0.001$ & $<0.05$ & $<0.01$ \\
DCD effect on $\mathrm{NH}_{4} \mathrm{ClNO}_{3}$ & $<0.001$ & $\mathrm{NS}$ & $\mathrm{NS}$ & $<0.001$ & $<0.001$ & $<0.05$ & $<0.01$ \\
\hline
\end{tabular}

NS $=$ not significant at $P<0.05 ; \mathrm{LSD}$ at $P=0.05$.
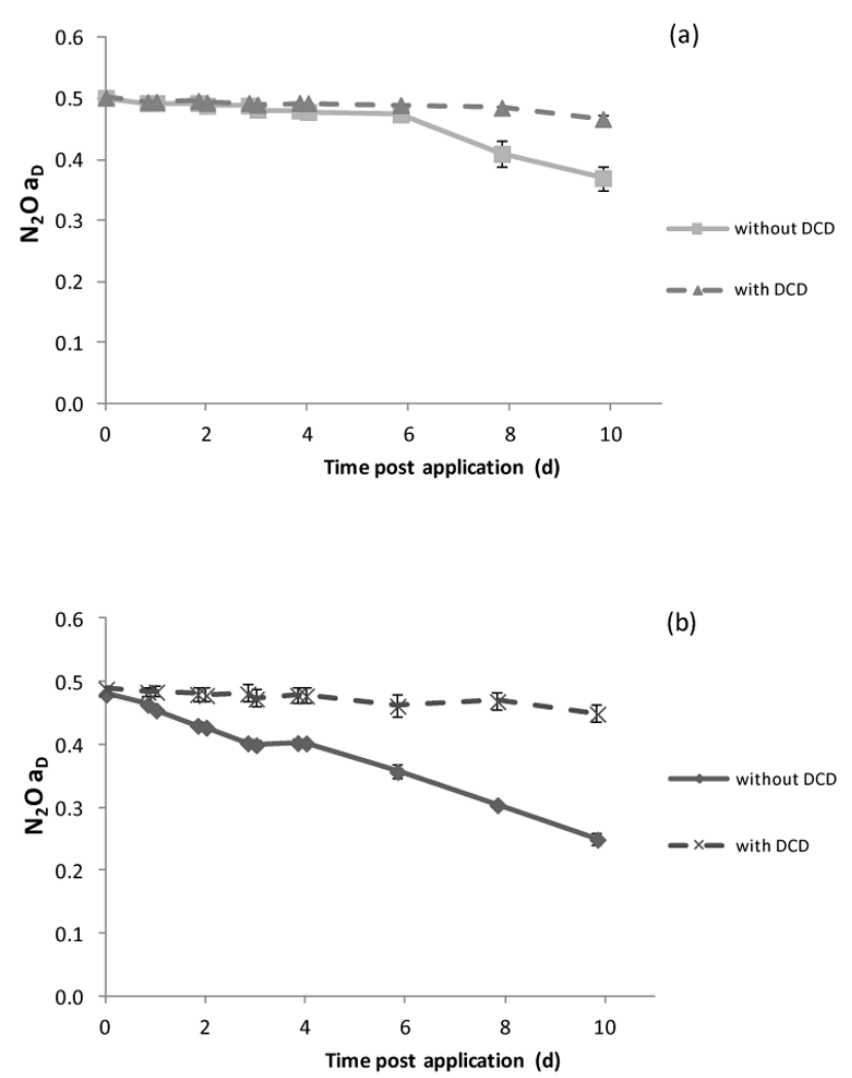

Fig. 4. Change in the ${ }^{15} \mathrm{~N}$ mole fraction of the labelled nitrate pool $\left(a_{D}\right)$ over time in March 2009 for ${ }^{14} \mathrm{CS}^{15} \mathrm{NO}_{3}$ (a) and for ${ }^{14} \mathrm{NH}_{4} \mathrm{Cl}^{15} \mathrm{NO}_{3}$ (b) with and without DCD. Error bars indicate standard error.

same as the theoretical enrichment of 0.50 atom fraction ${ }^{15} \mathrm{~N}\left(50\right.$ atom $\left.\%{ }^{15} \mathrm{~N}\right)$. At all application times $a_{\mathrm{D}}$ values for $\mathrm{CSNO}_{3}$ were higher than $a_{\mathrm{D}}$ for $\mathrm{NH}_{4} \mathrm{ClNO}_{3}$, indicating that the rate of nitrification was slower for $\mathrm{CSNO}_{3}$ than for $\mathrm{NH}_{4} \mathrm{ClNO}_{3}$ (March 2009, $P<0.001$; July 2009, $P<0.01$; October 2009, $P<0.01$; March 2010, $P<0.001$; June 2010,
$P<0.01$; October 2010, NS; March 2011, $P<0.001)$. Examining the change in $\mathrm{N}_{2} \mathrm{O} a_{\mathrm{D}}$ with time, it was apparent that the presence of CS caused a delay in nitrification (Fig. 4). The application of DCD caused the values of $a_{\mathrm{D}}$ in $\mathrm{CSNO}_{3}$ to be significantly higher compared to the $\mathrm{CSNO}_{3}$ without DCD treatment on five occasions (March 2009, $P<0.001$; March 2010, $P<0.05$; June 2010, $P<0.001$; October 2010, $P<0.05$; March 2011, $P<0.01)$ as the rate of decrease in $a_{\mathrm{D}}$ was slower in the presence of DCD. When DCD was applied to $\mathrm{NH}_{4} \mathrm{CINO}_{3}$, the values of $a_{\mathrm{D}}$ in $\mathrm{NH}_{4} \mathrm{ClNO}_{3}$ were significantly higher than the $\mathrm{NH}_{4} \mathrm{ClNO}_{3}$ without DCD treatment on the same five occasions (March 2009, $P<0.001$; March 2010, $P<0.001$; June 2010, $P<0.001$; October 2010, $P<0.05$; March 2011, $P<0.01)$. DCD did not have a significant effect on $\mathrm{N}_{2} \mathrm{O} a_{\mathrm{D}}$ in either the $\mathrm{CSNO}_{3}$ or $\mathrm{NH}_{4} \mathrm{ClNO}_{3}$ treatments in July and October 2009. Enrichment of $\mathrm{N}_{2} \mathrm{O}$ from the ${ }^{15} \mathrm{NH}_{4}$-labelled treatments increased with time (Fig. 5) suggesting that ${ }^{15} \mathrm{~N}$ labelled ammonium was oxidized through the nitrification process, enriching the $\mathrm{NO}_{3}$ pool, from which ${ }^{15} \mathrm{~N}_{2} \mathrm{O}$ was evolved.

$\mathrm{N}_{2} \mathrm{O} d_{\mathrm{D}}$ is the fraction of the emitted $\mathrm{N}_{2} \mathrm{O}$ which is derived from the ${ }^{15} \mathrm{~N}$-labelled denitrifying nitrate pool, with a $\mathrm{N}_{2} \mathrm{O}$ $d_{\mathrm{D}}$ value of unity (1.00) indicating that $100 \%$ of the $\mathrm{N}_{2} \mathrm{O}$ emitted is from the nitrate pool. Values of $\mathrm{N}_{2} \mathrm{O} d_{\mathrm{D}}$ (Table 4) for $\mathrm{CSNO}_{3}$ with and without DCD were not significantly different from unity; therefore the source of the $\mathrm{N}_{2} \mathrm{O}$ emitted from the $\mathrm{CSNO}_{3}$ treatments was the nitrate pool. Values of $\mathrm{N}_{2} \mathrm{O} d_{\mathrm{D}}$ for $\mathrm{NH}_{4} \mathrm{ClNO}_{3}$ were significantly lower than unity in March 2009, March 2010, June 2010 and March 2011 with values of $0.96,0.90,0.65$, and 0.87 being measured, indicating that $4,10,35$ and $13 \%$, respectively, of the $\mathrm{N}_{2} \mathrm{O}$ emitted was derived from a natural abundance nitrate pool. DCD did not significantly change $\mathrm{N}_{2} \mathrm{O} d_{\mathrm{D}}$ in either the $\mathrm{CSNO}_{3}$ or $\mathrm{NH}_{4} \mathrm{ClNO}_{3}$ treatments. 
Table 4. The fraction of $\mathrm{N}_{2} \mathrm{O}$ derived from the labelled nitrate pool $\left(d_{\mathrm{D}}\right)$ during peak $\mathrm{N}_{2} \mathrm{O}$ emissions for $\mathrm{CSNO}_{3}$ and $\mathrm{NH}_{4} \mathrm{ClNO}_{3}$ with and without DCD.

\begin{tabular}{lrrrrrrr}
\hline & Mar-09 & Jul-09 & Oct-09 & Mar-10 & Jun-10 & Oct-10 & Mar-11 \\
\hline $\mathrm{CSNO}_{3}$ without DCD & 0.99 & 1.00 & 0.98 & 0.96 & 0.88 & 0.99 & 0.94 \\
$\mathrm{CSNO}_{3}$ with DCD & 0.99 & 1.00 & 0.96 & 0.96 & 0.89 & 0.99 & 0.96 \\
$\mathrm{NH}_{4} \mathrm{ClNO}_{3}$ without DCD & 0.96 & 0.97 & 0.95 & 0.90 & 0.65 & 0.98 & 0.87 \\
$\mathrm{NH}_{4} \mathrm{ClNO}_{3}$ with DCD & 0.98 & 0.93 & 0.96 & 0.88 & 0.65 & 0.97 & 0.76 \\
\hline Difference from unity: & & & & & & & \\
$\mathrm{CSNO}_{3}$ without DCD & $\mathrm{NS}$ & $\mathrm{NS}$ & $\mathrm{NS}$ & $\mathrm{NS}$ & $\mathrm{NS}$ & $\mathrm{NS}$ & $\mathrm{NS}$ \\
$\mathrm{CSNO}_{3}$ with DCD & $\mathrm{NS}$ & $\mathrm{NS}$ & $\mathrm{NS}$ & $\mathrm{NS}$ & $\mathrm{NS}$ & $\mathrm{NS}$ & $\mathrm{NS}$ \\
$\mathrm{NH}_{4} \mathrm{ClNO}_{3}$ without DCD & $<0.01$ & $\mathrm{NS}$ & $\mathrm{NS}$ & $<0.05$ & $<0.001$ & $\mathrm{NS}$ & $<0.05$ \\
$\mathrm{NH}_{4} \mathrm{ClNO}_{3}$ with DCD & $<0.05$ & $\mathrm{NS}$ & $\mathrm{NS}$ & $<0.05$ & $<0.001$ & $\mathrm{NS}$ & $<0.05$ \\
\hline $\mathrm{CSNO}_{3}$ vs. NH $\mathrm{NHINO}_{3}$ & $<0.001$ & $\mathrm{NS}$ & $\mathrm{NS}$ & $<0.05$ & $<0.001$ & $\mathrm{NS}$ & $<0.01$ \\
$\mathrm{DCD}_{4}$ effect on CSNO & $\mathrm{NS}$ & $\mathrm{NS}$ & $\mathrm{NS}$ & $\mathrm{NS}$ & $\mathrm{NS}$ & $\mathrm{NS}$ & $\mathrm{NS}$ \\
$\mathrm{DCD}_{3}$ effect on $\mathrm{NH}_{4} \mathrm{ClNO}$ & $\mathrm{NS}$ & $\mathrm{NS}$ & $\mathrm{NS}$ & $\mathrm{NS}$ & $\mathrm{NS}$ & $\mathrm{NS}$ & $\mathrm{NS}$ \\
\hline
\end{tabular}

NS $=$ not significant at $P<0.05 ;$ LSD at $P=0.05$.

\section{Discussion}

\section{$5.1 \quad \mathrm{~N}_{2} \mathrm{O}$ and $\mathrm{N}_{2}$ cumulative emissions}

$\mathrm{N}_{2} \mathrm{O}$ and $\mathrm{N}_{2}$ cumulative emissions were expressed as a percentage of the applied $\mathrm{N}$ (ammonium- $\mathrm{N}$ and nitrate- $\mathrm{N}$ ). In our study, over the seven treatment dates, between 0.4-8.7\% of the applied $\mathrm{N}\left(\mathrm{NH}_{4}^{+}\right.$and $\left.\mathrm{NO}_{3}^{-}\right)$was lost as $\mathrm{N}_{2} \mathrm{O}$ and between 2.1-23.2\% was lost as $\mathrm{N}_{2}$ in the $\mathrm{CSNO}_{3}$ treatment. When $\mathrm{NH}_{4} \mathrm{ClNO}_{3}$ was applied, between $0.3-4.8 \%$ was lost as $\mathrm{N}_{2} \mathrm{O}$ and $1.7-20.4 \%$ was lost as $\mathrm{N}_{2}$. Lowest emissions were measured when soil moisture was low. The current IPCC default $\mathrm{N}_{2} \mathrm{O}$ emission factor is $1 \%$ of the applied $\mathrm{N}$, regardless of $\mathrm{N}$ source (organic-N or fertiliser-N) (IPCC, 2006). The current study did not include unfertilized control plots; therefore, emission factors could not be calculated. However, the average percentage $\mathrm{N}_{2} \mathrm{O}$ and $\mathrm{N}_{2}$ losses expressed in terms of $\mathrm{N}$ applied indicate that $\mathrm{N}$ gas losses are large, with increased losses in the presence of CS. The total cumulative emission of $\mathrm{N}_{2} \mathrm{O}-\mathrm{N}$ plus $\mathrm{N}_{2}-\mathrm{N}$, averaged over the seven measurement periods, expressed as a percentage of the available $\mathrm{N}$ applied was $15.9 \%$ for $\mathrm{CSNO}_{3}$ without DCD, $12.4 \%$ for $\mathrm{CSNO}_{3}$ with DCD, $12.4 \%$ for $\mathrm{NH}_{4} \mathrm{ClNO}_{3}$ with DCD, and $8.7 \%$ for $\mathrm{NH}_{4} \mathrm{ClNO}_{3}$ without DCD.

The simultaneous application of cattle slurry and $\mathrm{NO}_{3}$ induced a large increase in cumulative $\mathrm{N}_{2} \mathrm{O}$ emissions compared to those measured from $\mathrm{NH}_{4} \mathrm{Cl}$ combined with $\mathrm{NO}_{3}$, with increases of between 1.27 and 6.93 fold being measured. This increase indicates that the easily mineralisable carbon components in cattle slurry promoted $\mathrm{N}_{2} \mathrm{O}$ emissions derived from $\mathrm{NO}_{3}$. Lampe et al. (2006) found that the application of slurry and mineral fertiliser increased $\mathrm{N}_{2} \mathrm{O}$ emissions by between 30 to $150 \%$ compared to emissions from CAN alone following the application in spring to a grassland soil. This effect has been reported in a number of other studies (Stevens and Laughlin, 2001a, 2002; Dittert et al., 2005; Velthof and Oenema, 1993).

The use of the ${ }^{15} \mathrm{~N}$ tracer technique allowed the simultaneous measurement of $\mathrm{N}_{2} \mathrm{O}$ and $\mathrm{N}_{2}$, and hence the $\mathrm{N}_{2} \mathrm{O}$ mole fraction $\left(\mathrm{N}_{2} \mathrm{O} /\left(\mathrm{N}_{2} \mathrm{O}+\mathrm{N}_{2}\right)\right)$ to be calculated. The application of $\mathrm{CS}$ and $\mathrm{NO}_{3}$ significantly increased $\mathrm{N}_{2}$ emissions in March 2009 and March 2011. CS did not have an effect on $\mathrm{N}_{2}$ emission at any other time. Previous studies have reported a range of $\mathrm{N}_{2} \mathrm{O}$ mole fractions: Mathieu et al. (2006) reported a range of 0.15-0.94 measured from undisturbed soil cores following the application of ${ }^{15} \mathrm{~N}$-nitrate after $2 \mathrm{~h}$. Stevens and Laughlin (2001a) measured an average $\mathrm{N}_{2} \mathrm{O}$ mole fraction of 0.31 for $\mathrm{NH}_{4} \mathrm{HCO}_{3} \mathrm{NO}_{3}$ and 0.66 for $\mathrm{CSNO}_{3}$. Despite the high variability of reported values for $\mathrm{N}_{2} \mathrm{O}$ mole fractions, the current study showed that an increase in the $\mathrm{N}_{2} \mathrm{O}$ mole fraction occurred on each of the seven occasions when CS was applied with nitrate to grassland soils, compared to $\mathrm{NH}_{4} \mathrm{ClNO}_{3}$. This increase in $\mathrm{N}_{2} \mathrm{O}$ mole fraction was due to the increase in $\mathrm{N}_{2} \mathrm{O}$ emissions in the presence of CS. Averaged across the seven application dates, the mole fraction was 0.34 for $\mathrm{CSNO}_{3}$ compared to 0.24 for $\mathrm{NH}_{4} \mathrm{ClNO}_{3}$. The average $\mathrm{N}_{2} \mathrm{O}$ mole fraction was lower (0.19) in June 2010, under relatively dry conditions, than at other times (average 0.34 ), indicating a lower $\mathrm{N}_{2} \mathrm{O}$ mole fraction under conditions more conducive to nitrification.

\section{$5.2 \quad \mathrm{~N}_{2} \mathrm{O} a_{\mathrm{D}}$ and $\mathrm{N}_{2} \mathrm{O} d_{\mathrm{D}}$}

As the occurrence of nitrification can be inferred from the rate of dilution of the labelled nitrate pool, $\mathrm{N}_{2} \mathrm{O} a_{\mathrm{D}}$ results have demonstrated that the rate of nitrification in $\mathrm{CSNO}_{3}$ was slower than in $\mathrm{NH}_{4} \mathrm{ClNO}_{3}$, with a delay in the onset of nitrification occurring in the $\mathrm{CSNO}_{3}$ treatments. The application of a readily available organic carbon source to the soil stimulates microbial respiration and causes a subsequent decrease 

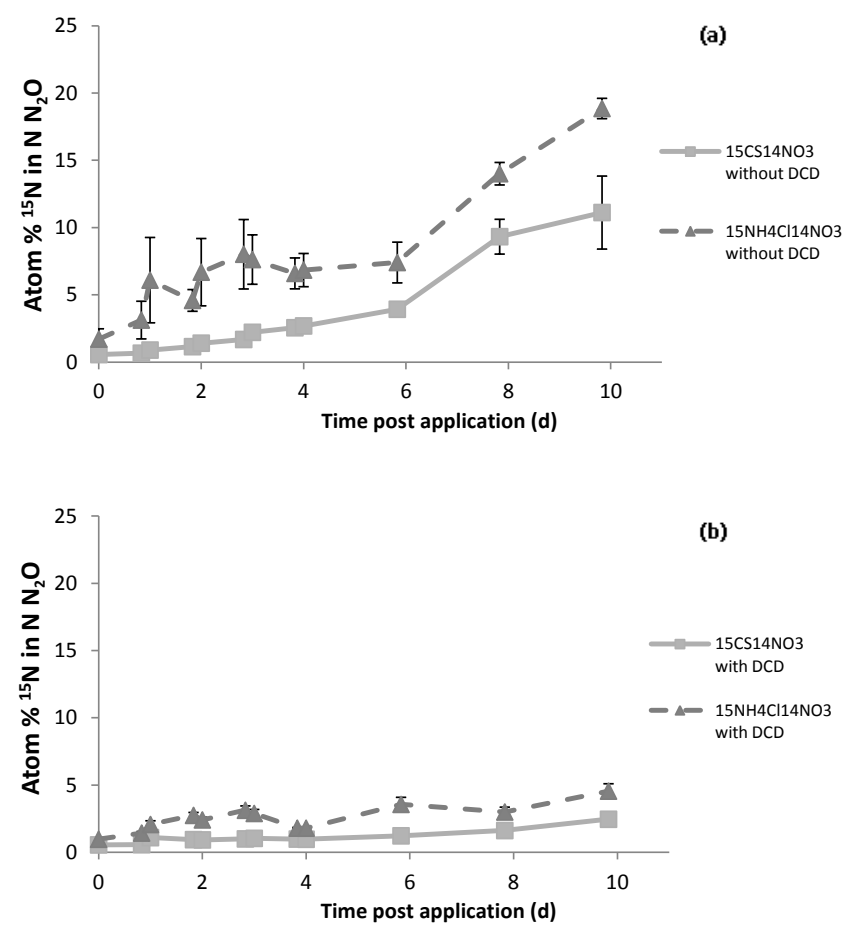

Fig. 5. Change in atom $\%{ }^{15} \mathrm{~N}$ in $\mathrm{N}_{2} \mathrm{O}$ over time in March 2009 for ${ }^{15} \mathrm{CS}^{14} \mathrm{NO}_{3}$ and ${ }^{15} \mathrm{NH}_{4} \mathrm{Cl}^{14} \mathrm{NO}_{3}$ without DCD (a) and with DCD (b). Error bars indicate standard error.

in oxygen concentration in the soil pore space (Tiedje, 1988). Stevens and Laughlin (2001a) also found that the application of CS increased soil respiration, thus creating conditions where $\mathrm{NO}_{3}$ would be used as the terminal-electron acceptor instead of $\mathrm{O}_{2}$.

In the current study, although nitrification often occurred it only made a significant contribution $(35 \%)$ to the $\mathrm{N}_{2} \mathrm{O}$ flux in June 2010. At this time there was zero rainfall indicating that the dry soil conditions favoured nitrification. CS $d_{\mathrm{D}}$ values were not different from unity; hence, all $\mathrm{N}_{2} \mathrm{O}$ came from the denitrifying nitrate pool, as the metabolism of the carbon source in the slurry enhanced anaerobic conditions. When CS was not present, the $\mathrm{N}_{2} \mathrm{O} d_{\mathrm{D}}$ values for $\mathrm{NH}_{4} \mathrm{ClNO}_{3}$ treatments were lower than those for $\mathrm{CSNO}_{3}$ providing further evidence that nitrification rates were more rapid in the $\mathrm{NH}_{4} \mathrm{ClNO}_{3}$ treatments.

\subsection{Effect of DCD}

The $\mathrm{N}_{2} \mathrm{O} a_{\mathrm{D}}$ values in both the $\mathrm{CSNO}_{3}$ and $\mathrm{NH}_{4} \mathrm{ClNO}_{3}$ treatments were significantly higher with than without DCD on five occasions; therefore DCD appeared to be effective in inhibiting the nitrification process. DCD did not affect the $\mathrm{N}_{2} \mathrm{O}$ $a_{\mathrm{D}}$ values in both $\mathrm{CSNO}_{3}$ and $\mathrm{NH}_{4} \mathrm{ClNO}_{3}$ treatments in July or October 2009. Cumulative rainfall over five days postapplication was 30.0 and $33.0 \mathrm{~mm}$ for July and October 2009, respectively. This suggested that either anaerobic conditions inhibited nitrification or that DCD moved down the soil profile post-application during this heavy rainfall, and therefore was not acting as a nitrification inhibitor on these occasions. Zerulla et al. (2001) highlighted that a shortcoming of using DCD was that it is susceptible to losses through leaching due to its high water solubility. Monaghan et al. (2009) showed that between 2 and $16 \%$ of the DCD applied annually could be lost in drainage water.

Overall DCD significantly lowered $(P<0.01)$ both $\mathrm{N}_{2} \mathrm{O}$ and $\mathrm{N}_{2}$ fluxes in March and October 2009, but only $\mathrm{N}_{2}$ fluxes in July 2009. It had no significant effect on cumulative emissions at other times. Although this study has found DCD to be an effective nitrification inhibitor by examining the changes in $\mathrm{N}_{2} \mathrm{O} a_{\mathrm{D}}$, its effectiveness was not always translated into a reduction in $\mathrm{N}_{2} \mathrm{O}$ emissions, when an ammonium- $\mathrm{N}$ (as mineral $\mathrm{N}$ or $\mathrm{CS}$ ) and nitrate- $\mathrm{N}$ fertiliser source were applied together. DCD did not alter the fraction of the emitted $\mathrm{N}_{2} \mathrm{O}$ which was derived from the denitrifying nitrate pool at any time in either the $\mathrm{CSNO}_{3}$ or the $\mathrm{NH}_{4} \mathrm{ClNO}_{3}$ treatments. As the source of $\mathrm{N}_{2} \mathrm{O}$ was found to be predominantly from the $\mathrm{NO}_{3}$ pool, the benefit in inhibiting $\mathrm{NH}_{4}^{+}-\mathrm{N}$ oxidation by DCD was too small to be seen against the large nitrate pool already present. Other studies have shown that DCD was effective in reducing $\mathrm{N}_{2} \mathrm{O}$ emissions from ammonium-based fertilisers (Dobbie and Smith, 2003; Skiba et al., 1993) and cattle slurries (Hatch et al., 2005; Merino et al., 2002). Skiba et al. (2003) found that $\mathrm{N}_{2} \mathrm{O}$ was predominantly produced by nitrification when soils were dry and DCD reduced emissions by at least $40 \%$. A recent study conducted at two grassland sites in Ireland found DCD to be highly effective, reducing $\mathrm{N}_{2} \mathrm{O}$ emissions from CS by up to $82 \%$ (Cahalan et al., 2012). The effect of DCD in lowering $\mathrm{N}_{2} \mathrm{O}$ emissions is limited in the presence of a $\mathrm{NO}_{3}$ source, when denitrification is the main source of $\mathrm{N}_{2} \mathrm{O}$.

\section{Conclusions}

The current study used the ${ }^{15} \mathrm{~N}$ tracer technique to simultaneously measure $\mathrm{N}_{2} \mathrm{O}$ and $\mathrm{N}_{2}$ emissions from cattle slurry in the presence of fertiliser $\mathrm{NO}_{3} . \mathrm{N}_{2} \mathrm{O}$ emissions were predominantly from denitrification of the $\mathrm{NO}_{3}$ pool. $\mathrm{N}_{2} \mathrm{O}$ emissions from $\mathrm{CS}$ in the presence of $\mathrm{NO}_{3}$ fertiliser were very high (0.4-8.7\% of applied $\mathrm{N}$ ) over a 20-day period, under mild moist conditions in Northern Ireland. Emissions were significantly larger from the CS treatment compared to the $\mathrm{NH}_{4} \mathrm{Cl}$ treatment, supplying the same rate of $\mathrm{N}$ as in the slurry. This was probably due to the easily mineralisable $\mathrm{C}$ components in the CS promoting $\mathrm{N}_{2} \mathrm{O}$ emissions from the added fertiliser $\mathrm{NO}_{3}$ pool. This study supports the view that organic fertilisers should not be applied at the same time as nitrate-based fertilisers, as significant increases in $\mathrm{N}_{2} \mathrm{O}$ emissions occur. The average $\mathrm{N}_{2} \mathrm{O}$ mole fraction $\left(\mathrm{N}_{2} \mathrm{O} /\left(\mathrm{N}_{2} \mathrm{O}+\mathrm{N}_{2}\right)\right)$ over all seven application dates was 0.34 for $\mathrm{CSNO}_{3}$ compared to 
0.24 for the $\mathrm{NH}_{4} \mathrm{ClNO}_{3}$ treatment, indicating the dominance of $\mathrm{N}_{2}$ emissions.

The rate of nitrification in $\mathrm{CSNO}_{3}$ was slower than in $\mathrm{NH}_{4} \mathrm{ClNO}_{3}$, and DCD effectively inhibited nitrification in both treatments. However, the effect of DCD in lowering $\mathrm{N}_{2} \mathrm{O}$ emissions is limited in the presence of a $\mathrm{NO}_{3}$ fertiliser, when denitrification is the main source of $\mathrm{N}_{2} \mathrm{O}$. To obtain the maximum cost-benefit of DCD in lowering $\mathrm{N}_{2} \mathrm{O}$ emissions, under mild moist conditions, it should not be applied to a nitrate containing fertiliser (e.g. AN or CAN), and therefore the application of DCD should be restricted to ammonium-based organic or synthetic fertilisers.

Acknowledgements. This research was funded by the Irish National Development Plan, through the Research Stimulus Fund (RSF 07 519), administered by the Irish Department of Agriculture, Food and the Marine. The authors would like to thank Michael Nicholson, Gareth Ridgway, Raymond Stewart, Briege McCarney, Elizabeth Anne Wasson and Jill Mellon (AgriFood and Biosciences Institute) for their help with field and lab work. We also thank Dave Mathews and Sally Dawson (Agri-Food and Biosciences Institute) for carrying out the statistical analyses.

Edited by: U. Skiba

\section{References}

Arah, J. R. M.: Apportioning nitrous oxide fluxes between nitrification and denitrification using gas-phase mass spectrometry, Soil Biol. Biochem., 29, 1295-1299, 1997.

Bailey, L. D.: Effects of temperature and roots on denitrification in a soil, Can. J. Soil Sci., 56, 79-87, 1976.

Bouwman, A. F.: Exchange of greenhouse gases between terrestrial ecosystems and the atmosphere, in: Soils and the greenhouse effect, edited by: Bouwman, A. F., John Wiley and Sons, Chichester, 100-120, 1990.

Bremner, J. M. and Mulvaney, C. S.: Nitrogen total, in: Methods of soil analysis Part 2, edited by: Page, A. L., Am. Soc. Agron., Madison, WIA, 595 pp., 1982.

Briggs, G. G.: Behaviour of nitrification inhibitor N-Serve in broadcast and incorporated applications to soil, J. Sci. Food Agric., 26, 1083-1092, 1975.

Cahalan, E., Ernfors, M., Müller, C., Devaney, D., Laughlin, R. J., Watson, C. J., Khalil, M. I., Hennessy, D., McGeough, K. L., and Richards, K. G.: Effects of the nitrification inhibitor dicyandiamide (DCD) on nitrous oxide and methane emissions after cattle slurry application, Agric. Ecosys. Environ., submitted, 2012.

Clayton, H., McTaggart, I. P., Parker, J., Swan, L., and Smith, K. A.: Nitrous oxide emissions from fertilised grassland: a 2-year study of the effects of $\mathrm{N}$ fertiliser form and environmental conditions, Biol. Fert. Soils, 25, 252-260, 1997.

Coyne, M. S. and Frye, W. W.: Nitrogen in soils: The N cycle, in: Encyclopaedia of Soils in the Environment, Vol. III., edited by: Hillel, D., Elsevier Ltd., 13-20, 2005.

Cuhel, J., Simek, M., Laughlin, R. L., Bru, D., Chenaby, D., Watson, C. J., and Philippot, L.: Insights into the effect of soil $\mathrm{pH}$ on $\mathrm{N}_{2} \mathrm{O}$ and $\mathrm{N}_{2}$ emissions and denitrifier community size and activity, Appl. Environ. Microbiol., 76, 1870-1878, 2010.

Davidson, E. A., Hart, S. C., Shanks, C. A., and Firestone, M. K.: Measuring gross nitrogen mineralization, immobilization, and nitrification by ${ }^{15} \mathrm{~N}$ isotopic pool dilution in intact soil cores, $\mathrm{J}$. Soil Sci., 42, 335-349, 1991.

Davidson, E. A., Keller, M., Erickson, H. E., Verchot, L. V., and Veldkamp, E.: Testing a conceptual model of soil emissions of nitrous and nitric oxide, Bioscience, 50, 667-680, 2000.

Dittert, K., Lampe, C., Gasche, R., Butterbach-Bahl, K., Wachendorf, M., Papen, H., Sattelmacher, B., and Taube, F.: Short-term effects of single or combined application of mineral $\mathrm{N}$ fertilizer and cattle slurry on the fluxes of radiatively active trace gases from grassland soil, Soil Biol. Biochem., 37, 1665-1674, 2005.

Dobbie, K. E. and Smith, K. A.: Impact of different forms of N fertilizer on $\mathrm{N}_{2} \mathrm{O}$ emissions from intensive grassland, Nutr. Cycl. Agroecosys., 67, 37-46, 2003.

Edmeades, D. C.: Nitrification and urease inhibitors, A review of the national and international literature on their effects on nitrate leaching, greenhouse gas emissions and ammonia volatilisation from temperature legume based pastoral systems, Environment Waikato Technical Report 2044/22, 2004.

Farmers Weekly, Reed Business Information Ltd., Surrey, England, 2012.

Firestone, M. K. and Tiedje, J. M.: Temporal change in nitrous oxide and dinitrogen from denitrification following onset of anaerobiosis, Appl. Environ. Microbiol., 38, 673-679, 1979.

Frolking, S. E., Mosier, A. R., Ojima, D. S., Li, C., Parton, W. J., Potter, C. S., Priesack, E., Stenger, R., Haberbosch, C., Dorsch, P., Flessa, H., and Smith, K. A.: Comparison of $\mathrm{N}_{2} \mathrm{O}$ emissions from soils at three temperate agricultural sites: simulations of year-round measurements by four models, Nutr. Cycl. Agroecosyst., 52, 77-105, 1998.

Granli, T. and Bøckman, O. C.: Nitrous oxide from agriculture, Norw. J. Agric. Sci., 12, 1-128, 1994.

Hall, S. J., Matson, P. A., and Roth, P. M.: $\mathrm{NO}_{\mathrm{x}}$ emissions from soil: implications for air quality modeling in agricultural regions, Annu. Rev. Energ. Env., 21, 311-346, 1996.

Hatch, D., Trindade, H., Cardenas, L., Carneiro, J., Hawkins, J., Scholefield, D., and Chadwick, D.: Laboratory study of the effects of two nitrification inhibitors on greenhouse gas emissions from a slurry-treated arable soil: impact of diurnal temperature cycle, Biol. Fertil. Soils, 41, 225-232, 2005.

Hendrickson, L. L. and Keeney, D. R.: Effect of some physical and chemical factors on the rate of hydrolysis of nitrapyrin (n-serve), Soil Biol. Biochem., 11, 47-50, 1979.

IPCC: IPCC Guidelines for national greenhouse gas inventories, prepared by the National Greenhouse Gas Inventories Programme, edited by: Eggleston, H. S., Buendia, L., Miwa, K., Ngara, T., and Tanabe, K., Volume 4, Chapter 11, $\mathrm{N}_{2} \mathrm{O}$ emissions from managed soils, and $\mathrm{CO}_{2}$ emissions from lime and urea application, IGES, Hayama, Japan, 11 pp., 2006.

Keeney, D. R., Fillery, I. R. P., and Marx, G. P.: Effect of temperature on the gaseous nitrogen products of denitrification in a silt loam soil, Soil Sci. Soc. Am. J., 43, 1124-1128, 1979.

Lampe, C., Dittert, K., Sattelmacher, B., Wachendorf, M., Loges, R., and Taube, F.: Sources and rates of nitrous oxide emissions from grazed grassland after application of ${ }^{15} \mathrm{~N}$-labelled mineral fertilizer and slurry, Soil Biol. Biochem., 38, 2602-2613, 2006. 
Liu, X. J., Mosier, A. R., Halvorson, A. D., Curtis, A. R., and Fusuo, S. Z.: Dinitrogen and $\mathrm{N}_{2} \mathrm{O}$ emissions in arable soils: Effect of tillage, $\mathrm{N}$ source and soil moisture, Soil Biol. Biochem., 39, 2362-2370, 2007.

Mathieu, O., Lévêque, J., Hénault, C., Milloux, M. J., Bizouard, F., and Andreux, F.: Emissions and spatial variability of $\mathrm{N}_{2} \mathrm{O}$, $\mathrm{N}_{2}$ and nitrous oxide mole fraction at the field scale, revealed with ${ }^{15} \mathrm{~N}$ isotopic techniques, Soil Biol. Biochem., 38, 941-951, 2006.

McTaggart, I. P., Douglas, H., Clayton, H., and Smith, K. A.: Nitrous oxide emission from slurry and mineral nitrogen fertiliser applied to grassland, in: Gaseous nitrogen emissions from grasslands, edited by: Jarvis, S. C. and Pain, B. F., CAB International, New York, 201-209, 1997.

Merino, P., Estavillo, J. M., Graciollo, L. A., Pinto, M., Lacuesta, M., Muñoz-Rueda, A., and Gonzalez-Murua, C.: Mitigation of $\mathrm{N}_{2} \mathrm{O}$ emissions from grassland by nitrification inhibitor and Actilith F2 applied with fertilizer and cattle slurry, Soil Use Manage., 18, 135-141, 2002.

Monaghan, R. M., Smith, L. C., and Ledgard, S. F.: The effectiveness of a granular formulation of dicyandiamide (DCD) in limiting nitrate leaching from a grazed dairy pasture, New Zeal. J. Agr. Res., 52, 145-149, 2009.

Mulvaney, R. L.: Determination of N-15-labeled dinitrogen and nitrous-oxide with triple-collector mass spectrometers, Soil Sci. Soc. Am. J., 48, 690-692, 1984.

Parkin, T. B.: Soil microsites as a source of denitrification variability, Soil Sci. Soc. Am. J., 51, 1194-1199, 1987.

Paul, J. W., Beauchamp, E. G., and Trevors, J. T.: Acetate, propionate, butyrate, glucose, and sucrose as carbon sources for denitrifying bacteria in soil, Can. J. Microbiol., 35, 754-759, 1989.

Puttanna, K., Gowda, N. M. N., and Rao, E.: Effect of concentration, temperature, moisture, liming and organic matter on the efficacy of the nitrification inhibitors benzotriazole, o-nitrophenol, m-nitroaniline and dicyandiamide, Nutr. Cycl. Agroecosys., 54, 251-257, 1999.

Ruser, R., Flessa, H., Russow, R., Schmidt, G., Buegger, F., and Munch, J. C.: Emission of $\mathrm{N}_{2} \mathrm{O}, \mathrm{N}_{2}$ and $\mathrm{CO}_{2}$ from soil fertilized with nitrate: Effect of compaction, soil moisture and rewetting, Soil Biol. Biochem., 38, 263-274, 2006.

Seitzinger, S. P. and Kroeze, C.: Global distribution of nitrous oxide production and $\mathrm{N}$ inputs in freshwater and coastal marine ecosystems, Global Biogeochem. Cy., 12, 93-113, 1998.
Simek, M. and Cooper, J. E.: The influence of soil pH on denitrification: progress towards the understanding of this interaction over the last 50 years, Eur. J. Soil Sci., 53, 345-354, 2002.

Skiba, U., Smith, K. A., and Fowler, D.: Nitrification and denitrification as sources of nitric-oxide and nitrous-oxide in a sandy loam soil, Soil Biol. Biochem., 25, 1527-1536, 1993.

Stevens, R. J. and Laughlin, R. L.: Measurement of nitrous oxide and di-nitrogen emissions from agricultural soils, Nutr. Cycl. Agroecosys., 52, 131-139, 1998.

Stevens, R. J. and Laughlin, R. L.: Cattle slurry affects nitrous oxide and dinitrogen emissions from fertilizer nitrate, Soil Sci. Soc. Am. J., 65, 1307-1314, 2001a.

Stevens, R. J. and Laughlin, R. L.: Lowering the detection limit for dinitrogen using the enrichment of nitrous oxide, Soil Biol. Biochem., 33, 1287-1289, 2001b.

Stevens, R. J. and Laughlin, R. J.: Cattle slurry applied before fertilizer nitrate lowers nitrous oxide and dinitrogen emissions, Soil Sci. Soc. Am. J., 66, 647-652, 2002.

Stevens, R. J., Laughlin, R. J., Atkins, G. J., and Prosser, S. J.: Automated determination of nitrogen-15 labeled dinitrogen and nitrous oxide by mass spectrometry, Soil Sci. Soc. Am. J., 57, 981988, 1993.

Stevens, R. J., Laughlin, R. J., Arah, J. R. M., and Hood, R. C.: Measuring the contributions of nitrification and denitrification to the flux of nitrous oxide from soil, Soil Biol. Biochem., 29, 139151, 1997.

Tiedje, J. M.: Ecology of denitrification and dissimilatory nitrite reduction to ammonium, Biology of anaerobic microorganisms, New York, Wiley, 179-244, 1988.

Velthof, G. L. and Oenema, O.: Nitrous oxide flux from nitric-acidtreated cattle slurry applied to grassland under semi-controlled conditions, Neth. J. Agr. Sci., 41, 81-93, 1993.

Weier, K. L., Doran, J. W., Power, J. F., and Walters, D. T.: Denitrification and the dinitrogen/nitrous oxide ratio as affected by soil water, available carbon, and nitrate, Soil Sci. Soc. Am. J., 57, 66-72, 1993.

Zerulla, W., Barth, T., Dressel, J., Erhardt, K., von Locquenghien, K. H., Pasda, G., Rädle, M., and Wissemeier, A. H.: 3,4Dimethylpyrazole phosphate (DMPP) - a new nitrification inhibitor for agriculture and horticulture, Biol. Fertil. Soils, 34, 7984, 2001. 